Биљана Ристовић

biljana.ristovic76@gmail.com

Гордана Бацотић

gbacotic@gmail.com

Народна библиотека Ужице
Стручни рад

UDK 025.43 .03

https://doi.org/10.18485/

bibliotekar.2018.60.1.4

\title{
СЛОБОДНО ОБЛИКОВАНА ПРЕДМЕТНА ОДРЕДНИЦА И ПОТРЕБЕ КОРИСНИКА
}

Сажетак: Овај рад бави се предностима коришћења слободно обликоване предметне одреднице у библиографској обради у COBISS систему. Иако систем предвиђа уношење слободно обликоване предметне одреднице у поље 610, претрагом COBISS.net-a утврђено је да се та могућност у COBIB.SR користи релативно ретко у односу на COBIB.SL. У пракси се показало да је концепт предметне одреднице неразумљив за просечног корисника приликом самосталне претраге каталога, па самим тим и претрага не даје задовољавајуће резултате. Претпоставка је да би употреба слободно обликоване предметне одреднице, уз обавезну контролисану предметну одредницу, прилагодила претрагу могућностима и потребама свих корисника.

Кључне речи: предметна каталогизација, слободно обликована предметна одредница, контролисана предметна одредница, поље 610, приступна тачка, COBISS.

Аутоматизација библиотечког пословања и прелазак са лисних на онлајн каталоге донели су нови квалитет у библиографској обради и проширили могућности претраживања. У лисним каталозима приступ записима био је могућ само преко аутора, наслова и предмета (елемената према којима су се улагали листићи), док у онлајн каталогу било који елемент описа може бити приступна тачка. ${ }^{1}$

1 Ilejn Svenonijus, Intelektualna osnova organizovanja informacija (Beograd: Narodna biblioteka Srbije: Clio, 2007), 44. 
Предметна одредница као приступна тачка користи се у ситуацији у којој кориснику нису познати назив дела или име аутора који се бави одређеним предметом. Формулисање предметне одреднице често је изазов за каталогизаторе, а њен концепт представља непознаницу за просечног корисника услуга библиотеке. Иако корисници најчешће претражују по предмету (теми), у пракси се испоставило да је ово претраживање најмање ефикасно. Начин на који каталогизатор формулише тему подразумева употребу одређених алата (тезауруси, нормативне базе, референсна литература, каталог националне библиотеке и др.), али се ипак дешава да усвојени термин није у складу са начином размишљања просечног корисника.

Упоредо са увођењем предметног каталога у библиотеке доносе се и стандарди који регулушу основна начела садржинске обраде документа. ${ }^{2}$ Стандарди се унапређују и надограђују како би испратили промене карактеристичне за информатичко доба и изашли у сусрет новим потребама корисника. Брзина развоја каталошке теорије мора да прати развој промена у друштву и да утиче на преобликовање каталошког система. ${ }^{3}$

Деведесетих година двадесетог века ИФЛА (International Federation of Library Associations and Institutions - Међународна федерација библиотечких удружења и институција) донела је начела за предметно означавање (Principles Underlying Subject Heading Languages) ${ }^{4}$ у покушају да уведе уједначавање предметне обраде на међународном нивоу. Постоји једанаест начела и она су подељена у две групе.

Прву групу чини девет начела за израду предметног система (начело јединствене одреднице, начело надзора синонима, начело надзора хомо-

2 Слободанка Тодоровић, „Садржинска информација у лисном и електронском каталогу”, у Преgметина класификација оg лисної gо елекииронскої кайалоїа, главни и одговорни уредник Љиљана Ђурђић (Београд: Народна библиотека Србије, 1999), 14.

3 Ана Савић, „Организација информација у савременим синдетичким каталозима и место предметне одреднице у њима”, Гласник Нарояне библиоиеке Србије год. 13 (2012/2013): 99.

4 Видети:

- Irena Galić Bešker, „Sadržajno označivanje ručno tiskanih knjiga u svjetlu međunarodnih preporuka", u Predmetna obrada: pogled unaprijed: zbornik radova, uredile Branka PurgarićKužić i Sonja Špiranec (Zagreb: Hrvatsko knjižničarsko društvo, 2017), 135-145;

- Alenka Šauperl, „IFLINE smernice za predmetno označevanje: prednosti in slabosti v luči spoznanj o vedênju uporabnikov", Knjižnica letn. 9, št. 1-2 (2005), https://knjiznica.zbds-zveza. si/knjiznica/article/view/5830 (преузето 3. 4. 2018);

- Vlasta Doležal, „Predmetna obrada u Nacionalnoj i sveučilišnoj knjižnici u Zagrebu: povratak načelima", Vjesnik bibliotekara Hrvatske vol. 49, no. 2 (rujan 2006): 35, https://hrcak.srce. hr/165677 file://D:/My\%20Documents/Downloads/04_VBH_2_2006_Dolezal.pdf (преузето 3. 4. 2018). 
нима, семаничко, синтаксичко, начело доследности, начело именовања, начело потврде у литератури, начело уважавања корисника). Начело јединствене одреднице подразумева да исти појам мора бити изражен једним, усвојеним термином, где је неопходно увести контролисање синонима, разрешење хомонима, као и успостављање семантичких веза међу појмовима (хијерархија, еквиваленција, асоцијација). Синтаксичко начело дефинише начин формирања сложених израза у предметној одредници, док се доследност очекује при примени правила за формирање предметне одреднице. Начело именовања подразумева постојање правилника у складу са којим се обликују имена и називи као предметне одреднице. Избор термина мора бити потврђен кроз литературу и употребу од стране корисника.

Другу групу чине два начела примене у пракси (израда правилника за предметну обраду и упутства за примену, као и начело специфичних одредница). Прво начело подразумева неопходност постојања правила која се односе на предметну обраду, а предмет су посебних докумената и правилника која доносе надлежна тела. Начело специфичне одреднице прописује да предметне одреднице тачно одговарају теми на коју се односе. ${ }^{5}$

Париска начела 1961. имала су за циљ међународну стандардизацију каталогизације, док је Изјава о међународним кайалошким начелима (2009) прилагодила ова начела онлајн каталозима.

У Изјави о међународним кайалошким начелима дефинисане су контролисане и слободно обликоване приступне тачке. Контролисане приступне тачке односе се на усвојене и варијантне облике имена, као што су ентитети или особе, породице, колективна тела, дела, изрази, појавни облици, јединице, појмови, објекти, догађаји и места. Оне треба да обезбеде конзистентност неопходну за лоцирање библиографских записа. Њихова контрола спроводи се кроз нормативне записе. Слободно обликоване тачке приступа односе се на имена, наслове, кодиране податке, кључне речи, који нису контролисани у нормативним записима. ${ }^{6}$

Принципи за израду каталошких правилника с једне стране инсистирају на речнику усклађеном са речником већине корисника, а с друге на стандардизацији израде приступних тачака:

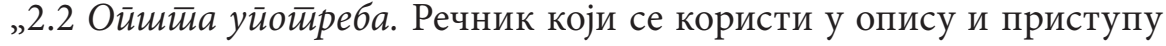
треба да буде усклађен са речником већине корисника;

5 Doležal, „Predmetna obrada...”, 35.

6 Međunarodna organizacija bibliotečkih udruženja i institucija, „Izjava o međunarodnim kataloškim načelima”, Гласник Нароgне библиотеке Србије год. 11, бр. 1 (2009): 100. 


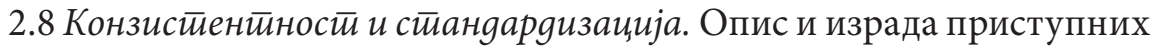
тачака треба да буде стандардизована у највећој могућој мери. То доприноси већој конзистентности, која, са своје стране, повећава могућност заједничког коришћења библиографских и нормативних података.?

Илејн Свенонијус наводи три основна критеријума за избор термина који улазе у контролисани предметни речник:

- потврда у литератури (термини који се јављају у скупу канонских текстова одређене дисциплине),

- потврда у употреби (термини које корисници користе у претрази),

- структурна потврда (термини који немају потврду ни у литератури ни у употреби, али служе да групишу специфичне термине и надокнаде везе које недостају у хијерархији). ${ }^{8}$

Имајући у виду ове принципе и начела, савремени онлајн каталози требало би да задовоље потребе корисника и њихове могућности, као и стандарде за библиографску обраду и каталошка начела.

Међутим, испоставило се да је у ери интернета претраживање библиотечких каталога компликовано за просечног корисника. Сматра се да већина данашњих библиотечких онлајн каталога не користи могућности веб окружења и да су задржали особине лисних каталога. Искуство у пракси показало је да је предметно претраживање библиотечких каталога најчешће, али обично не даје задовољавајуће резултате. Корисници су навикли на веб претраживаче, који су једноставни за употребу и интерактивни. Упити ретко остају без погодака, који су притом рангирани по релевантности. Предност интернет претраживача је у томе што се подразумева коришћење природног језика, док је за претрагу предметног каталога по теми потребно познавање нормираног језика.

Упркос начелима која у теорији стављају кориснике у први план, стиче се утисак да су у пракси потребе корисника жртвоване зарад поштовања норматива и стандарда.

„Када се обликује један систем за организовање информација, корисник је нужно у првом плану, али се понекад превиђа чињеница да су циљеви и начела, који су у темељу тих система, сачињени на основу корисничких потреба. ${ }^{9}$

\footnotetext{
7 Međunarodna organizacija bibliotečkih udruženja i institucija, „Izjava o međunarodnim...”, 9899.

8 Svenonijus, Intelektualna osnova organizovanja informacija, 185-186.

9 Isto, 8.
} 


\section{Корисничко означавање}

Са развојем Веб 2.0 сервиса појавила се могућност да корисници додају своје ознаке (тагове) за садржаје на интернету и тиме их учине видљивијим. Ова врста класификације назива се фолксономија. Термин је настао од речи фолкс (folks) - људи и таксономија (taxonomy) - наука о класификацији, а приписује се Томасу Вандер Волу.

Фолксономија се дефинише помоћу три елемента:

- извори (садржај који се означава корисничким ознакама),

- корисници (субјекти који означавају садржај),

- корисничке ознаке (слободно обликоване кључне речи). ${ }^{10}$

Постоје покушаји да се овај начин класификације примени на библиотечке каталоге, који су конципирани као затворени системи, са циљем да се приближе потребама корисника. Фолксономија као модел организације информација користи принцип „одоздо нагоре”. ${ }^{11}$ За разлику од предметне обраде, не постоји унапред одређена концепција ${ }^{12}$, већ корисници садржају додељују своје ознаке, а најбоље су оне које су најфреквентније.

Предности корисничког означавања огледају се у употреби природног језика блиског већини (потврда у употреби), већој исцрпности у означавању (покривене су и споредне теме) и специфичности корисничких ознака у односу на предметну одредницу која је општија и покрива главни садржај ентитета. Ова врста означавања не захтева ангажовање стручњака, бржа је и јефтинија, а нови термини лакше улазе у употребу јер не пролазе процедуру нормативне контроле. У недостатке корисничког означавања спадају: појава синонима, неразрешених хомонима, различите варијанте у писању одређеног појма, различити нивои специфичности ознаке у семантичком смислу, одсуство строге контроле процеса, што доводи до немогућности окупљања свих релевантних извора под истим појмом. ${ }^{13}$

10 Tomislav Ivanjko, „Korisničko označavanje i predmetni pristup”, u Predmetna obrada: pogled unaprijed: zbornik radova, uredile Branka Purgarić-Kužić i Sonja Špiranec (Zagreb: Hrvatsko knjižničarsko društvo, 2017), 42.

11 Thomas Vander Wal, „Folksonomy Coinage and Definition”, 2. february 2007, http://www. vanderwal.net/folksonomy.html (преузето 10. 4. 2018).

12 Sonja Spiranec i Blaža Livaja, „Korisničke oznake i predmetne odrednice: istraživanje funkcionalnosti kao prilog unapređenju predmetnog pristupa", Vjesnik bibliotekara Hrvatske vol. 57, no. 1/3 (2014): 53, https://hrcak.srce.hr/file/209867; file://D:/My\%20Documents/Downloads/ VBH_57_1_3_Spiranec_Livaja.pdf (преузето 3. 4.2018).

13 Tomislav Ivanjko, „Korisničko označavanje... ”, 46-47. 
Из наведених разлога корисничко означавање најбоље функционише за опис извора који се појављују на интернету, а карактерише их бројност и динамичност увођења нове терминологије, док би за потребе библиотека најекономичнија била комбинација контролисане предметне обраде и фреквентних израза из корисничких упита.

\section{Предметне одреднице у COBISS систему}

Библиографски опис у COBISS систему ради се у COMARC формату заснованом на Универзалном формату за машински читљиву каталогицају (UNIMARC). У блоку за садржинску анализу поља 600-609 намењена су контролисаним предметним одредницама, а поља 960-969 за неусвојене облике. У пољима 600-609 користи се контролисани језик, док се у пољима 960-969 користе термини који се јављају у стручној литератури, јавној употреби или у пракси приликом претраживања, а нису потврђени кроз нормативну контролу. Поља 960-969 представљају варијантни облик предметне одреднице и морају бити повезана са одговарајућим пољима 600-609. ${ }^{14}$ Структура поља 600-609 подразумева унос одреднице и пододредница које стоје у синтагматском односу.

У поље 610 уносе се слободно обликоване предметне одреднице, које не подлежу нормативној контроли. Поље се састоји из поновљивог потпоља $a$, тако да се може унети више независних предметних одредница и потпоља $z$, где се уноси трословни код за језик одредница.Одреднице се пишу малим словима, имају индикатор 1 или 2 који прави разлику између примарног израза (покрива главну тему или предмет) и секундарног израза (покрива мање значајан аспект дела). Индикатор 0 користи се када се не наглашава разлика између примарног и секундарног израза. ${ }^{15}$

Ова врста одредница уважава корисничке потребе јер се тема одређеног ентитета дефинише изразима који припадају природном језику. То могу бити изрази преузети из самог дела (кључне речи, апстракт, поглавља књиге) или изрази које корисници често користе при формулисању свог упита при самосталном претраживању каталога или при претраживању уз помоћ библиотекара.

14 COMARC/B, http://home.izum.si/IZUM/e_manuals_html/COMARC_B/scr/960.html (преузето 29. 3. 2018)

15 COMARC/B, http://home.izum.si/IZUM/e_manuals_html/COMARC_B/scr/610.html (преузето 29. 3. 2018). 


\section{Употреба поља 610 у COBISS.net систему}

У COBISS систему употреба поља 610 врло је неуједначена. Заступљеност поља 610 анализирана је у COBISS.net мрежи, у свакој од база чланица COBISS система: Србије, Словеније, Црне Горе, Босне и Херцеговине, Републике Српске, Македоније, Бугарске и Албаније. ${ }^{16}$

У COBIB.SL поље 610 врло често се користи: од укупно 5.111.765 записа, са слободно обликованом предметном одредницом има 3.267.295 (64\%). У COBIB.SR од укупног броја записа (3.223.643), 114.486 записа има попуњено поље 610 (3,5 \%). (Слика 1)

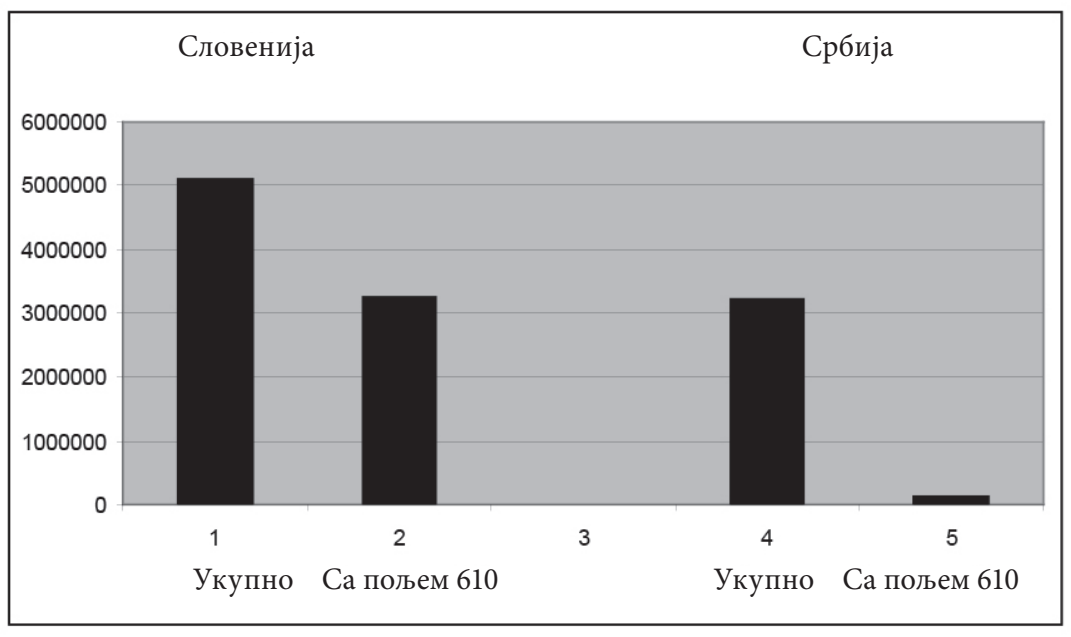

Слика 1

У COBIB.CG има 7\% записа са слободно обликованом предметном одредницом (471.134 према 34.302); у СОВІВ.ВН 24\% (467.383, према 113.576); У COBIB.MK 3 \% (604.553 према 19.967); у COBIB.RS 1\% (177.179, према 2.287); у COBIB.BG, од 1.014.017 записа у само 3, која су преузета из СОВIB. SL, постоји слободно обликована предметна одредница; у COBIB.AL 45\% (106.817 према 48.365). ${ }^{17}$ Највећи број записа у којима се јавља поље 610 на нивоу целе мреже креирано је у COBIB.SL и преузето у друге базе.

16 За укупан број записа са пољем 610 формиран је израз за претраживање: ID=“*“" and DU=“*“.

17 Према стању у COBISS.net бази на нивоу каталогизације на дан 8. 3. 2018. 
У COBIB.SR од 114.486 записа са попуњеним пољем 610, 66.138 су записи за саставне делове, 45.990 за монографске публикације и 2.358 записа за друге врсте грађе. (Слика 2)

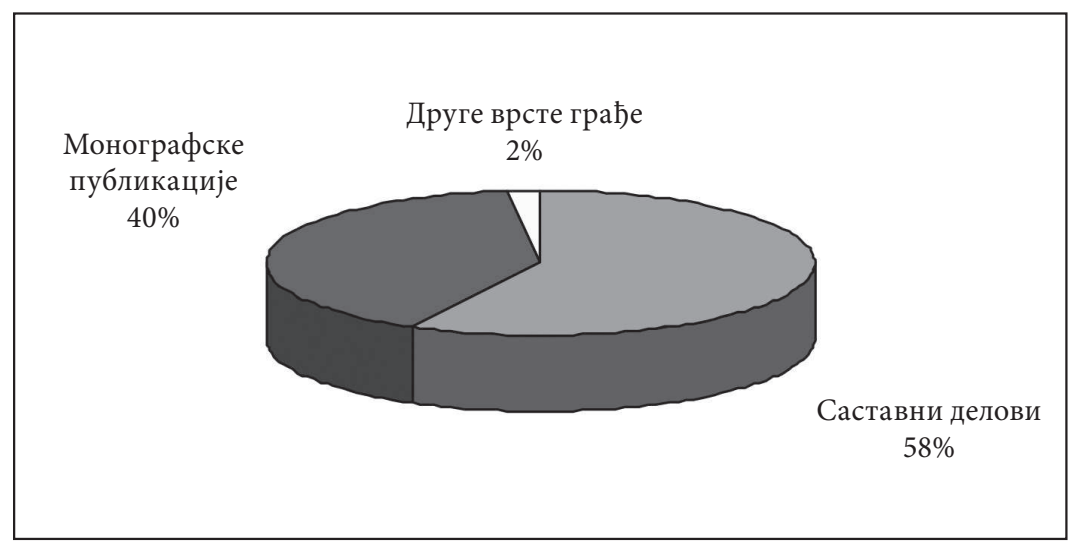

Слика 2

Слободно обликована предметна одредница јавља се као једина одредница у запису или у комбинацији са усвојеном одредницом. У СОВIВ. SR у записима за саставне делове око 75\% (49.683) има унету само слободно обликовану предметну одредницу, а око 25\% (16.455) слободну у комбинацији са контролисаном предметном одредницом.

Код монографских публикација ситуација је обрнута: само слободно обликовану предметну одредницу има 35\% (15.913) записа, а слободно обликовану и контролисану одредницу заједно 65\% (30.077) записа. ${ }^{18}$ Притом, значајан број записа са слободно обликованом предметном одредницом у COBIB.SR преузет је углавном из COBIB.SL, а пракса је да се постојеће одреднице из преузетих записа не бришу.

\section{Предности употребе поља 610}

Поље 610 не може да замени поља 600-609 јер је без контролисане предметне одреднице немогуће груписати сва дела која говоре о истом предмету. Погодност коју пружа употреба поља 610 у односу на комбина-

18 Према стању у бази COBIB.SR (преко COBISS.net мреже на нивоу каталогизације) на дан 8. 3. 2018. 
цију поља 600-609 и 900-969 односи се првенствено на исцрпност описа ентитета.

Усвојена предметна одредница и њене варијанте покривају главну тему дела и теже ка општем. У пракси се користи релативно мали број контролисаних предметних одредница у једном запису. Конгресна библиотека од 1996. додељује до 10 предметних одредница како би се потпуније описао садржај. ${ }^{19}$ Слободно обликована предметна одредница пружа могућност да се општији термин разложи на хијерархијски ниже термине, за које постоји већа вероватноћа да ће се наћи у корисничком упиту. Иако начело специфичне одреднице прописује прецизно дефинисање теме, тежња да се са што мање одредница покрије цео садржај документа у пракси доводи до употребе хијерархијски вишег појма, који је сувише уопштен за потребе корисника.

Такође, слободно обликована предметна одредница може да покрије и споредне аспекте дела, који су значајни за корисника, али неће бити покривени кроз систем усвојених и варијантних одредница. Поред тога, постоји и већа слобода у избору термина који се могу користити за опис садржаја. У једном пољу 610 може бити већи број независних неусвојених одредница у односу на поља 9XX и оне нису организоване у синтагматском низу, већ се уносе у поновљиво потпоље $a$. Такође, у поље се могу унети и одреднице на страном језику.

У поље 610 могу се унети појмови из садржаја, кључне речи које уз рад даје аутор, као и изрази које корисници често користе у упитима. Једна од предности описа садржаја преко кључне речи је у брзој и једноставној садржинској класификацији дела за коју није неопходна велика стручност каталогизатора. ${ }^{20}$

Приликом рада са корисницима библиотекари се у захтевима за претраживање сусрећу са изразима који се не поклапају са усвојеним предметним одредницама. Изрази који се често понављају могли би да постану неконтролисана приступна тачка у пољу 610. Како у COBISS систему нису предвиђени прикупљање и обрада корисничких упита, ту улогу могли би да преузму библиотекари који раде са корисницима и предложе најфреквентније термине библиотекарима каталогизаторима. На овај начин при-

19 K. Golub, „Predmetno pretraživanje u knjižničnim katalozima s web-sučeljem” (magistarska teza, Filozofski fakultet, Sveučilište u Zagrebu, 2003), 34, http://darhiv.ffzg.unizg.hr/id/eprint/2349/1/ Magisterij-hrv.pdf (преузето 3. 4. 2018).

20 Бојана Веселиновић, „Предметне одреднице и кључне речи”, Гласник Народне библиотеке Србије год. 13 (2012/2013): 109. 
менило би се, условно речено, корисничко означавање, које би имало неку врсту надзора или контроле.

У онлајн каталозима, корисници најчешће претражују преко кључне речи, јер им је концепт предметне одреднице нејасан. Ова врста претраге води у две крајности: добија се превише или премало погодака.

Преко кључних речи могуће је претражити садржај готово свих поља у библиографском запису (наслов, напомене, сажетак - који се врло ретко уноси, предметне одреднице, слободно обликоване предметне одреднице), чиме се добија велики број погодака, међу којима је мало релевантних (велики одзив, али мала прецизност). Према И. Свенонијус приступ преко кључне речи служи за идентификацију и налажење, док приступ преко контролисаног речника служи за груписање података. ${ }^{21}$

Корисников упит најчешће је унитерм из природног језика. Искуство из праксе показало је да корисници у претрази најчешће користе конкретне термине, који су хијерархијски нижи у односу на термине у предметној одредници, тако да упит може остати без погодака, ако се термин не јавља у библиографском опису (најчешће у наслову). Употребом слободно обликованих предметних одредница, чији избор се заснива на начелу потврде у употреби, повећава се број неконтролисаних приступних тачака, које нису ограничене ни библиографским описом ни контролисаним речником. Коришћењем слободно обликованих предметних одредница уз контролисане предметне одреднице смањује се вероватноћа да ће упит бити без погодака (термин из упита ће се поклопити са термином из слободно обликоване предметне одреднице).

Употребом овог поља каталогизација се приближава препознавању потреба корисника јер се повећава могућност да се претрагом преко кључне речи добије релевантан резултат. Иако је у пракси другачије, слободно обликована предметна одредница не би требало да постоји у запису без контролисане предметне одреднице. У предметној обради потребно је избећи јединствени циљни погодак, што значи да одредница треба да буде „прецизна и адекватна, али довољно широка да обједини више дела сличног садржаја". ${ }^{22}$

Слободно обликована предметна одредница посебно је погодна за обраду саставних делова чије су теме уско стручне и где се обично кори-

21 Svenonijus, I. Intelektualna osnova organizovanja informacija, 126.

22 Срђан Славнић, „Класе циљних погодака у библиографској бази података као фактор контроле и структурирања предметних одредница", Савремена библиотека год. 20, бр. 25 (2008): 16. 
сте кључне речи које је аутор издвојио, а код монографских публикација за представљање секундарних аспеката садржаја. Она може корисника да упути на усвојену предметну одредницу, уколико у запису таква постоји. У COBISS систему усвојене предметне одреднице су хиперлинковане, тако да корисник једним кликом долази до скупа свих погодака груписаних истом предметном одредницом.

\section{Закључак}

У COBIB.SR систему слободно обликована предметна одредница релативно ретко се користи. У пракси се показало да је предметно претраживање за просечног корисника компликовано и неефикасно. COBISS нема развијен систем који би кориснички упит без погодака на једноставан начин усмерио ка усвојеним предметним одредницама. Чешћим коришћењем слободно обликованих предметних одредница, уз обавезне контролисане предметне одреднице, могао би се делимично надоместити тренутни несклад између могућности система и потреба просечног корисника.

\section{Литература:}

1. COMARC/B, http://home.iзum.si/IZUM/e_manuals_html/COMARC_B/scr/960. html (preuseto 29. 3. 2018).

2. Doležal, Vlasta. „Predmetna obrada u Nacionalnoj i sveučilišnoj knjižnici u Zagrebu: povratak načelima”. Vjesnik bibliotekara Hrvatske vol. 49, no. 2 (rujan 2006): 33-49, https://hrcak.srce.hr/165677file://D:/My\%20Documents/Downloads/04_ VBH_2_2006_Dolezal.pdf (preuzeto 3. 4.2018).

3. Galić Bešker, Irena. „Sadržajno označivanje ručno tiskanih knjiga u svjetlu međunarodnih preporuka". U Predmetna obrada: pogled unaprijed: zbornik radova, uredile Branka Purgarić-Kužić i Sonja Špiranec (Zagreb: Hrvatsko knjižničarsko društvo, 2017), 132-148.

4. Golub, K. „Predmetno pretraživanje u knjižničnim katalozima s web-sučeljem. Magistarska teza, Filozofski fakultet, Sveučilište u Zagrebu, 2003.

5. http://darhiv.ffzg.unizg.hr/id/eprint/2349/1/Magisterij-hrv.pdf (preuzeto 3. 4. 2018).

6. Ivanjko, Tomislav. „Korisničko označavanje i predmetni pristup”. U Predmetna obrada: pogled unaprijed: zbornik radova, uredile Branka Purgarić-Kužić i Sonja Špiranec, 38-56. Zagreb: Hrvatsko knjižničarsko društvo, 2017. 
7. Međunarodna organizacija bibliotečkih udruženja i institucija. „Izjava o međunarodnim kataloškim načelima“. Glasnik Narodne biblioteke Srbije god. 11, br. 1 (2009): 97-108. (na ćirilici)

8. Savić, Ana. „Organizacija informacija u savremenim sindetičkim katalozima i mesto predmetne odrednice u njima”. Glasnik Narodne biblioteke Srbije god. 13 (2012/2013): 97-105. (na ćirilici)

9. Slavnić, Srđan. „Klase ciljnih pogodaka u bibliografskoj bazi podataka kao faktor kontrole i strukturiranja predmetnih odrednica". Savremena biblioteka god. 20, br. 25 (2008): 12-17. (na ćirilici)

10. Svenonijus, Ilejn. Intelektualna osnova organizovanja informacija. Beograd: Narodna biblioteka Srbije; Clio, 2007.

11. Šauperl, Alenka. „IFLINE smernice za predmetno označevanje: prednosti in slabosti v luči spoznanj o vedênju uporabnikov. Knjižnica letn. 9, št. 1-2 (2005): 9-26, https://knjiznica.zbds-zveza.si/knjiznica/article/view/5830 (preuzeto 3. 4. 2018) ili https://knjiznica.zbds-zveza.si/knjiznica/article/view/5830.

12. Špiranec, Sonja i Blaža Livaja. „Korisničke oznake i predmetne odrednice: istraživanje funkcionalnosti kao prilog unapređenju predmetnog pristupa”. Vjesnik bibliotekara Hrvatske vol 57, no. 1/3 (2014): 51-68.

13. Todorović, Slobodanka. „Sadržinska informacija u lisnom i elektronskom katalogu". U Predmetna klasifikacija od lisnog do elektronskog kataloga, urednik Ljiljana Đurđić, 11-20. Beograd: Narodna biblioteka Srbije, 1999. (na ćirilici)

14. Veselinović, Bojana. „Predmetne odrednice i ključne reči”. Glasnik Narodne biblioteke Srbije god. 13 (2012/2013): 107-112. (na ćirilici) 
Biljana Ristović

biljana.ristovic76@gmail.com

Gordana Bacotić

gbacotic@gmail.com

Public Library of Užice

\title{
UNCONTROLLED SUBJECT TERMS AND USER NEEDS
}

\begin{abstract}
This paper deals with the benefits of using an uncontrolled subject heading in the bibliographic cataloguing in COBISS system. Although the system provide use of an uncontrolled subject heading in field 610, COBISS.net research has found that this option in COBIB.SR is used relatively rarely compare to COBIB.SL. In practice, it turned out that the concept of the subject headings is complicated and incomprehensible to users, and consequently the search doesn't give satisfactory results. The assumption is that the usage of uncontrolled subject headings in combination with controlled subject headings would adjusted the search to the capabilities and needs of all users.
\end{abstract}

Kew words: subject cataloguing, uncontrolled subject heading, controlled subject heading, field 610, access point, COBISS.

Примљено: 14. априла 2018. Прихваћено: 11. маја 2018. 